\title{
Pengembangan Instrumen Penilaian Kepuasan Pasien terhadap Pelayanan Kefarmasian di Rumah Sakit
}

Development of the Instrument Patient Satisfaction for Pharmaceutical Services in Hospital

\section{Dedy Almasdy ${ }^{1}$, Yulihasri ${ }^{2}$ Dila Deria Putri ${ }^{3}$}

Keywords: instrument development, patient

satisfaction, hospital pharmacy, clinical pharmacy.

Kata kunci: pengembangan instrumen, kepuasan pasien, pelayanan kefarmasian, farmasi rumah sakit.
ABSTRACT: Instrument to assessing patient satisfaction to hospital pharmacy services has developed. The instrument consists of two dimensions which are friendly explanation and managing theraphy. The result of instrument developing are a instrument which have fair to good of the level of agreement $(k=0.53)$, fair to good validity $(r>0.632)$ and good reliability (cronbach alpha $=0.97)$.

ABSTRAK: Telah dilakukan pengembangan insrumen untuk pengukuran kepuasan pasien terhadap pelayanan kefarmasian yang diberikan oleh suatu rumah sakit. Instrumen terdiri atas dua dimensi yaitu penjelasan yang bersahabat (friendly explanation) dan pengelolaan terapi (managing theraphy). Hasil pengembangan didapatkan suatu instrumen dengan tingkat kesepahaman yang cukup baik $(k=0.53)$, valid $(r>0,632)$ dan reliabel (cronbach alpha $=0,97$ )

${ }^{1}$ Fakultas Farmasi Universitas Andalas

${ }^{2}$ Fakultas Ekonomi Universitas Andalas

${ }^{3}$ RSUD Pasaman Barat

Korespondensi:

Dedy Almasdy

(dedyalmasdy@gmail.com) 


\section{PENDAHULUAN}

Kepuasan pasien terhadap kualitas pelayanan farmasi merupakan indikator yang penting dalam mutu pelayanan kesehatan di rumah sakit (1). Kualitas pelayanan dikatakan baik dan memuaskan jika jasa yang diterima sesuai atau melebihi dari yang diharapkan, sebaliknya kualitas pelayanan dikatakan jelek atau tidak memuaskan jika pelayanan yang diterima lebih rendah dari yang diharapkan (2). Tingkat kepuasan pasien tersebut dapat diukur dengan menggunakan instrumen berupa kuesioner sebagai alat ukurnya.

Berbagai instrumen telah dikembangkan dalam mengukur kepuasan pasien. Akan tetapi pasar (market) pada sektor perumahsakitan mempunyai kekhususan tertentu dibandingkan dengan pasar pada sektor lainnya, yang dalam ekonomi, hal ini diistilahkan dengan pasar yang tidak alamiah (unnatural market). Dengan demikian konsumen rumah sakit mempunyai karakteristik yang berbeda dengan konsumen lain secara umum.

Mengatasi masalah tersebut Larson dkk telah mengembangkan suatu instrumen yang khusus digunakan untuk pengukuran kepuasan pasien terhadap pelayanan farmasi, dengan menggunakan model ideal referent (3). Pengembangan instrumen ini dilakukan melalui 3 tahap, yaitu; fase I (Pretest) dengan jumlah responden 30 pasien di klinik Tucson Arizona, uji fase II dengan 350 pasien dan uji fase III dengan 519 pasien. Pada awalnya instrumen ini dikembangkan dari 55 atribut pertanyaan dalam 12 dimensi. Setelah dilakukan uji validitas dan reabilitas mengerucut menjadi 44 pertanyaan dalam 10 dimensi kepuasan pasien, diantaranya: penjelasan (explanation), perhatian (consideration), kemampuan teknis (technical competence), aspek keuangan (financial aspects), kemudahan akses (accessibility), keefektifan obat-obatan (efficacy of medications), ketersediaan obat-obat OTC (OTC avaibility), kualitas obat (drug quality), kepuasan umum (general satisfaction), dan keberlanjutan ke apotik (continuity with the pharmacy).

Selanjutnya instrumen ini pada tahun 2002 diperbarui dan divalidasi menjadi 20 atribut pertanyaan yang terdiri dari dua dimensi, yaitu friendly explanation dan managing theraphy (4). Instrumen ini telah digunakan untuk mengukur kepuasan pasien terhadap pelayanan farmasi diberbagai negara, antara lain; Nigeria (5), Brazil (6) dan Macedonia (6).

Di Indonesia, berbagai instrumen telah dikembangkan dalam mengukur tingkat kepuasan pasien terhadap pelayanan yang diberikan oleh suatu rumah sakit, demikian juga terhadap pelayanan kefarmasian yang diberikan oleh instalasi farmasi rumah sakit. Akan tetapi pengembangan instrumen ini murni menggunakan pendekatan pengukuran kepuasan pelanggan secara umum. Sementara pasien rumah sakit mempunyai kekhususan tertentu dibandingkan pelanggan secara umum, sebagaimana yang telah disampaikan di atas. Berdasarkan hal di atas dikembangkan instrumen yang secara khusus akan digunakan untuk mengukur tingkat kepuasan pasien terhadap pelayanan farmasi rumah sakit di Indonesia.

\section{METODE PENELITIAN}

Pengembangan instrumen dilakukan 
Tabel 1. Variabel, indikator dan nomor pertanyaan pada instrumen untuk mengukur kepuasan pasien terhadap pelayanan farmasi (Larson et al, 2002)

\begin{tabular}{lll}
\hline Variabel & \multicolumn{1}{c}{ Indikator } & \multicolumn{1}{c}{ Nomor Pertanyaan } \\
\hline Kepuasan & $\begin{array}{l}\text { 1. Penjelasan yang } \\
\text { bersahabat (Friendly } \\
\text { Explanation) } \\
\text { Pasien }\end{array}$ \\
& $1,2,3,4,5,6,7,8,9,10,11$ \\
& 1. Pengelolaan terapi \\
& (Managing Theraphy)
\end{tabular}

atas dasar instumen yang telah dikembangkan oleh Larson dkk (4). Langkah pertama intrumen diterjemahkan kepada versi Bahasa Indonesia. Untuk menghindari bias budaya (cross cultural issues), ketepatan terjemahan instrumen kepada versi Bahasa Indonesia dievaluasi oleh dua orang ahli (peer opinion), selanjutnya tingkat kesepahaman antar kedua ahli tersebut dianalisis secara statistik (7). Penilaian terhadap tingkat kesesuaian para pakar didasarkan pada skala likert yang terdiri dari 5 kategori yaitu: (1) tidak sesuai, (2) kurang sesuai, (3) cukup sesuai, (4) sesuai, dan (5) sangat sesuai. Selanjutnya kuesioner dilakukan uji validitas dan reliabilitas untuk mengetahui apakah isi dari butir pertanyaan dalam suatu kuesioner valid dan reliabel. Adapun variabel, indikator, dan nomor pertanyaan yang digunakan pada instrumen sebagaimana yang dinyatakan pada Tabel 1 .

\section{HASIL DAN DISKUSI}

Table 2 memperlihatkan hasil penilaian para pakar terhadap instrumen versi Bahasa Indonesia dari instrumen yang telah dikembangkan oleh Larson dalam bentuk tabel kontingensi.

Selanjutnya dilakukan penghitungan nilai kappa untuk menetukan tingkat kesesuaian antara para pakar. Dari hasil perhitungan, didapatkan nilai kappa statistik sebesar 0,53 dengan nilai persentase kesesuaian antara pakarnya sebesar $75 \%$. Dengan demikian ada kesesuaian yang cukup (fair to good) antara nilai pengamatan kedua pakar dengan nilai perkiraan yang seharusnya diberikan ke dua pakar tersebut (8), sebagaimana yang dinyatakan pada Tabel 3.

Selanjutnya dilakukan uji validitas terhadap instrumen kepuasan pasien versi Bahasa Indonesia. Validitas instrumen menggambarkan bahwa suatu instrumen benar-benar mampu mengukur variabelvariabel yang akan diukur dalam penelitian serta mampu menunjukkan tingkat kesesuaian antara konsep dan hasil pengukuran, dalam hal ini adalah tingkat kepuasan pasien terhadap pelayanan kefarmasian yang diberikan oleh suatu instalasi farmasi rumah sakit.

Penentuan tingkat signifikansi dilakukan dengan membandingkan nilai r hitung dengan nilai $r$ tabel untuk degree of freedom $=n-k$ dalam hal ini 10-2 atau df 8 pada pengujian 
Tabel 2. Hasil penilaian pakar terhadap versi Bahasa Indonesia instrument Larson

\begin{tabular}{cccccc}
\hline Pakar I & Pakar II Jumlah & Pakar I & Pakar II & Jumlah \\
\hline 1 & 1 & 0 & 3 & 4 & 3 \\
1 & 2 & 0 & 3 & 5 & 0 \\
1 & 3 & 0 & 4 & 1 & 0 \\
1 & 4 & 0 & 4 & 2 & 0 \\
1 & 5 & 0 & 4 & 3 & 0 \\
2 & 1 & 0 & 4 & 4 & 3 \\
2 & 2 & 0 & 4 & 5 & 0 \\
2 & 3 & 0 & 5 & 1 & 0 \\
2 & 4 & 0 & 5 & 2 & 2 \\
2 & 5 & 0 & 5 & 3 & 0 \\
3 & 1 & 0 & 5 & 4 & 0 \\
3 & 2 & 0 & 5 & 5 & 12 \\
3 & 3 & 0 & & & \\
\hline
\end{tabular}

Tabel 3. Pedoman penentuan tingkat kesesuaian

\begin{tabular}{cl}
\hline Nilai Kappa & Kesesuaian \\
\hline$>0,75$ & Baik (excellent) \\
$0,4-0,75$ & Cukup (fair so good) \\
$<0,4$ & Buruk (poor) \\
\hline
\end{tabular}

Sumber: Singgih, 2008

Tabel 4. Hasil perhitungan analisis validitas dimensi penjelasan yang bersahabat (Friendly Explanation)

\begin{tabular}{cccc}
\hline $\begin{array}{c}\text { Nomor } \\
\text { Instrumen }\end{array}$ & r-hitung & r-tabel & Keputusan \\
\hline 1 & 0,866 & 0,632 & Valid \\
2 & 0,732 & 0,632 & Valid \\
3 & 0,815 & 0,632 & Valid \\
4 & 0,810 & 0,632 & Valid \\
5 & 0,766 & 0,632 & Valid \\
6 & 0,880 & 0,632 & Valid \\
7 & 0,801 & 0,632 & Valid \\
8 & 0,755 & 0,632 & Valid \\
9 & 0,869 & 0,632 & Valid \\
10 & 0,891 & 0,632 & Valid \\
11 & 0,854 & 0,632 & Valid \\
\hline
\end{tabular}


Tabel 5. Hasil perhitungan analisis validitas dimensi pengelolaan terapi Managing Theraphy

\begin{tabular}{cccc}
\hline $\begin{array}{c}\text { Nomor } \\
\text { Instrumen }\end{array}$ & r-hitung & r-tabel & Keputusan \\
\hline 12 & 0,815 & 0,632 & Valid \\
13 & 0,861 & 0,632 & Valid \\
14 & 0,770 & 0,632 & Valid \\
15 & 0,807 & 0,632 & Valid \\
16 & 0,802 & 0,632 & Valid \\
17 & 0,889 & 0,632 & Valid \\
18 & 0,819 & 0,632 & Valid \\
19 & 0,797 & 0,632 & Valid \\
20 & 0,718 & 0,632 & Valid \\
\hline
\end{tabular}

Tabel 6. Hasil perhitungan analisis reabilitas instrumen

\begin{tabular}{llcc}
\hline No & Dimensi & Alpha Cronbach & Keputusan \\
\hline 1. & Friendly explanation & 0,959 & Reliabel \\
2. & Managing theraphy & 0,952 & Reliabel \\
\hline & Total & 0,976 & Reliabel \\
\hline
\end{tabular}

pengujian satu arah dengan alpha 0,05 , sehingga didapat $r$ tabel sebesar 0,632. Jika $r$ hitung untuk $r$ tiap butir pertanyaan bernilai positif dan lebih besar dari $r$ tabel, maka butir pertanyaan tersebut dinyatakan valid (9). Dengan menggunakan bantuan SPSS for windows versi 16 diperoleh hasil sebagai Tabel 4 untuk dimensi penjelasan yang bersahabat (Friendly Explanation) dan Tabel 5 untuk dimensi pengelolaan terapi (Managing Theraphy).

Pengujian reabilitas menunjukkan bahwa kuesioner tersebut konsisten mengukur variabel-variabel yang akan diukur apabila dilakukan pengukuran yang berulang. Butir pertanyaan dikatakan reliabel atau handal apabila jawaban seseorang secara berulang terhadap pertanyaan adalah konsisten. Suatu variabel dikatakan reliabel jika memberikan nilai cronbach alpha $>0,60$ (9). Dari pengujian menggunakan SPSS for windows versi 16 diperoleh hasil yang tertera pada tabel 6 .

\section{KESIMPULAN}

Pada pengembangan instrumen yang telah dilakukan didapatkan suatu instrumen pengukuran kepuasan pasien terhadap pelayanan kefarmasian di rumah sakit dengan tingkat kesepakatan ahli yang cukup baik $(k=0.53)$, valid $(r>0.632)$ dan reliabel (cronbach alpha 0.97). 


\section{DAFTAR PUSTAKA}

1. Farris K, Kirking D. 1993. Assessing the quality of pharmaceutical care: Application of the concepts of quality assessment from medical care. Ann Pharmacother, 215-223.

2. Supranto, J. 2001. Pengukuran tingkat kepuasan pelanggan. PT.Rineka Cipta: Jakarta.

3. Larson L, Mackeigan L. 1989. Development and validation of an instrument to measure patient satisfaction with pharmacy services. Med Care, 522-536.

4. Larson L, Rovers J, Mackeigan L. 2002. Patient satisfaction with pharmaceutical care: update of validated instrument. J.Am. Pharm Assoc, 44-50.

5. Azuka C, Enato F, Obehi A. 2004. Assessment of patient satisfaction with pharmaceutical services in a Nigerian teaching hospital. The International

Journal of Pahrmacy Practice, 7-12.

6. Azeredo T, Maria A, Vena L, Angela E, Monica R. 2009. User satisfaction with pharmacy services in the Brazilian National STD/AIDS Program: Validity and Reability Issue. Cad Saude Publica, 1597-1609.

7. Zoran S, Bogdan V, Aleksandra K, Zorica N, Ljubica S. 2010. Assessment of patient satisfaction with pharmaceutical community services in Republic Macedonia. Macedonian Pharmaceutical Bulletin, 23-28.

8. Paul K, Gray C. 2008. SPSS 15 Made Simple. Psychology Press. New York.

9. Singgih S. Panduan lengkap menguasai SPSS 16. Elex Media Komputindo. Jakata. 2008.

10. Danang, S. 2010. Uji Khi Kuadrat dan Regresi untuk Penelitian Edisi I. Graha IImu: Yogyakarta. 